Kark, R. M., Croome, R. R. M., Cawthorpe, J., Bell, D. M., Bryans, A., MacBeth, R. J., Johnson, R. E., Consolazio, F. C., Poulin, J. L., Taylor, F. H. L. \& Cogswell, R. C. (1948-9). F. appl. Physiol. I, 73.

Kark, R. M., Johnson, R. E. \& Lewis, J. S. (1945). War Med., Chicago, 7, 345.

Kark, R. M., McCreary, J. F., Johnson, R. E., Melson, R. R. \& Richardson, L. M. (1944). Cold Weather Operational Trials of Rations Conducted at Prince Albert, Saskatchewan, Canada. Ottawa: Edmond Cloutier.

Kark, R. M. \& Muehrcke, R. C. (1952). Lancet, 262, I 189.

Lauber, H. J. \& Rosenfeld, W. (1938). Klin. Wschr. 17, 1587.

I evenson, S. M., Green, R. W., Taylor, F. H. L., Robinson, P., Page, R. C., Johnson, R. E. \& Lund, C. C. (1946). Ann. Surg. r24, 840 .

Lind, J. (1753). A Treatise of the Scurvy, Ist ed. Edinburgh: Sands, Murray and Cochran for A. Kincaid and A. Donaldson.

Long, C. N. H. (1947). Fed. Proc. 6, 46r.

Lund, C. C., Levenson, S. M., Green, R. W., Page, R. W., Robinson, P. E., Adams, M. A., MacDonald, A. H., Taylor, F. H. L. \& Johnson, R. E. (1947). Arch. Surg. 55, 557.

Manson-Bahr, P. M. (1925). Scurvy in the Tropics. In Tropical Diseases, 8th ed. [P. Manson-Bahr, editor.] New York: William Woods and Co.

McCollum, E. V. (1918). F. Amer. med. Ass. 71, 937.

Nadel, E. M. \& Schneider, J. J. (195I). F. clin. Endocrinol, 11, 79 I.

Rynearson, E. H. (1953). (Personal communication.)

Sayers, G. \& Sayers, M. A. (1949). Ann. N.Y. Acad. Sci. 50, 522.

Schoenberger, J. A., Dyniewicz, J. M., Rix, D., Nesby, C. \& Kark, R. M. (1953). (Unpublished data.)

Scott, R. F. (1923). Scott's Last Expedition. New York: Dodd Mead and Co.

Selye, H. (1946). F. clin. Endocrinol. 6, I 17 .

Stefanini, M. \& Rosenthal, M. C. (1950). Proc. Soc. exp. Biol., N.Y., 75, 806.

Stein, H. J., Bader, R. A., Eliot, J. W. \& Bass, D. E. (1949). F. clin. Endocrinol. 9, 529.

Stein, H. J., Eliot, J. W. \& Bader, R. A. (1948-9). Ұ. appl. Physiol. I, 575.

Stewart, C. P., Horn, D. B. \& Robson, J. S. (1953). Biochem. F. 53, 254.

Stewart, C. T., Salmon, R. J. \& May, C. D. (1952). F. Lab. clin. Med. 40, 657.

Taussky, H. H., Swan, R. C. \& Shorr, E. (I95I). In Proceedings of the Second Clinical ACTH Conference. Vol. r. Research. [J. R. Mote, editor.] New York: The Blakiston Co.

Treager, H. S., Gabuzda, G. J., Zamencheck, N. \& Davidson, C. S. (195I). Proc. Soc. exp. Biol., N.Y., 75, 517.

Wright, A. E. (I900). Lancet, ii, 565 .

Wright, A. E. (1908). Lancet, ii, 725.

Zilva, S. S. (1930). Biochem. F. 24, 1687 .

\title{
Aminoaciduria in Infancy and Ascorbic-acid Deficiency*
}

\section{By J. P. Dustin And E. J. Bigwood, Department of Biochemistry, Faculty of Medicine, Université Libre de Bruxelles}

It has been reported from various laboratories that free amino-acids are found in the urine of newborn infants, in relatively larger amounts than in urines of children or adults, and even more so in prematurity. According to Dent's major contribution to the subject of aminoaciduria in general, a distinction should be made between aminoaciduria resulting from a raised blood level ('overflow mechanism') and from a defect of kidney function ('renal mechanism') (Crumpler, Dent, Harris, \& Westall, I95 I). He has also recognized various patterns of aminoaciduria in adults, involving eventually genetic factors.

* The present paper is part of a more extensive study of one of us (J.P.D.) on aminoaciduria in general to be published in the future. Its expenses were covered by a grant from the Centre National de Recherches sur la Nutrition, Institut Belge de l'Alimentation et de la Nutrition, Brussels. 
According to Jonxis (I95I) amino-acid excretion may also be influenced by nutritional factors in infants, particularly when the latter are born prematurely. He reported on the occasion of a seminar on infant metabolism held in Leiden in $195^{\circ}$ under the auspices of W.H.O. that in urines passed by premature babies fed on boiled mother's milk poor in vitamin $\mathrm{C}$, the $a$-amino-acid nitrogen level might reach $10-15 \mathrm{mg} / 100 \mathrm{ml}$., that when vitamin $\mathrm{C}$ was added to that diet, the level dropped to $8 \mathrm{mg}$; that on cow's milk poor in vitamin $\mathrm{C}$ the level rose to at least 20-30 $\mathrm{mg}$, and that vitamin $\mathrm{C}$ added to this last diet produced again a drop of the level to some $10 \mathrm{mg} / 100 \mathrm{ml}$. He noticed also, from paper chromatographic tests that on mother's milk, the infants' urine seemed to contain chiefly threonine, serine, tryptophan, possibly lysine and arginine and no cystine, whereas on cow's milk the urine seemed to contain chiefly cystine, glycine and alanine.

In two infants showing clinical signs of scurvy, he found large amounts of aminoacids in the urine, equivalent to an output of $3-4 \mathrm{~g}$ in $24 \mathrm{~h}$, a large proportion of which corresponded to conjugated glycine. Jonxis referred to the impaired function of collagen synthesis in vitamin $\mathrm{C}$ deficiency, and raised the question whether this might possibly have some bearing upon the high glycine output in the urine. He finally reported that vitamin $\mathrm{C}$ treatment contributed to a substantial drop in the amino-acid output in the urine of his young scorbutic patients.

More recently Jonxis, Smith \& Huisman (1952) have also shown that children with rickets excrete more free and bound amino-acids than normal, and that calciferol tends to reduce the output of amino-acids although usually not entirely to normal levels.

The present contribution deals with the study of the influence of vitamin $\mathrm{C}$ on nitrogen metabolism in newborn infants, namely with regard to the urinary excretion of free amino-acids.

There are obviously many factors involved in the process of amino-acid excretion, but the complexity of the problem is also due to the difficulty in comparing appropriately the phenomenon as it occurs in adults with that in infants, when the process is examined not merely from the qualitative point of view but when it is considered on a quantitative basis. Values for concentration alone in urine samples may be misleading. Absolute values for output in $24 \mathrm{~h}$ in infant urines are obviously not comparable per se to those for adults. When we compared the findings with three subjects, an adult, an infant born at term and a premature infant, we chose as a basis for comparison the amounts in mg of free amino-acids found in $24 \mathrm{~h}$ urine specimens per $100 \mathrm{mg}$ of total nitrogen (Dustin, Moore \& Bigwood, 1952). We found that, whereas the adult excreted in the free form $10.4 \mathrm{mg}$ of the $\alpha$-amino-acids usually found in proteins, the infant born at term excreted $22 . \mathrm{I} \mathrm{mg}$ and the premature infant $35.2 \mathrm{mg}$. These values were obtained by Moore \& Stein's chromatographic method on ion exchange columns (Moore \& Stein, 1951; Schram, Dustin, Moore \& Bigwood, I953a,b). The distribution of amino-acids is summarized in Table $\mathrm{I}$.

The present paper deals with the case of another infant of 7 days of age, born at term and fed on an artificial diet since birth. This diet consisted of $7 \%$ Eledon 
Table $\mathrm{I}$. Output of free a-amino-acids in $\mathrm{mg}$ amino-acid/100 $\mathrm{mg}$ total nitrogen in 24 h specimens of urine

\begin{tabular}{|c|c|c|c|}
\hline Percentage & Adult man & $\begin{array}{l}\text { Infant, } 25 \text { days } \\
\text { old, born at } \\
\text { term }\end{array}$ & $\begin{array}{l}\text { Premature infant, } \\
3^{8} \text { days old, born } \\
\text { at } 5^{\frac{3}{4}} \text { months of } \\
\text { pregnancy }\end{array}$ \\
\hline $5^{-8}$ & & Glycine & $\begin{array}{l}\text { Glycine } \\
\text { Threonine }\end{array}$ \\
\hline I -5 & $\begin{array}{l}\text { Histidine } \\
\text { Lysine } \\
\text { Serine } \\
\text { Glycine }\end{array}$ & $\begin{array}{l}\text { Histidine } \\
\text { Lysine } \\
\text { Serine } \\
\text { Glutamic acid } \\
\text { Aspartic acid } \\
\text { Proline } \\
\text { Alanine } \\
\text { Cystine }\end{array}$ & $\begin{array}{l}\text { Histidine } \\
\text { Lysine } \\
\text { Serine } \\
\text { Glutamic acid } \\
\text { Aspartic acid } \\
\text { Proline } \\
\text { Alanine } \\
\text { Cystine } \\
\text { Methionine } \\
\text { Isoleucine } \\
\text { Tyrosine }\end{array}$ \\
\hline$<1$ & $\begin{array}{l}\text { Threonine } \\
\text { Valine } \\
\text { Methionine } \\
\text { Isoleucine } \\
\text { Leucine } \\
\text { Phenylalanine } \\
\text { Aspartic acid } \\
\text { Glutamic acid } \\
\text { Proline } \\
\text { Alanine } \\
\text { Tyrosine } \\
\text { Arginine }\end{array}$ & $\begin{array}{l}\text { Threonine } \\
\text { Valine } \\
\text { Methionine } \\
\text { Isoleucine } \\
\text { Leucine } \\
\text { Phenylalanine }\end{array}$ & $\begin{array}{l}\text { Leucine } \\
\text { Phenylalanine }\end{array}$ \\
\hline Trace or nil & $\begin{array}{l}\text { Cystine } \\
\text { Tryptophan }\end{array}$ & Tryptophan & $\begin{array}{l}\text { Arginine } \\
\text { Tryptophan }\end{array}$ \\
\hline $\begin{array}{l}\text { Fight essential } \\
\text { amino-acids } \\
\text { Ten other } \\
\text { amino-acids }\end{array}$ & $\begin{array}{l}2 \cdot 3 \\
8 \cdot I\end{array}$ & $\begin{array}{r}4.5 \\
17 \cdot 6\end{array}$ & $12 \cdot 0$ \\
\hline Total & 10.4 & $22 \cdot I$ & $35 \cdot 2$ \\
\hline
\end{tabular}

(The Nestlé Company Ltd., Hayes, Middlesex; buttermilk, containing $3 \mathrm{I} \%$ cow's milk protein) and 5\% Nutromalt (A. Wander Ltd., King's Langley, Hertfordshire; maltose and saccharose, protein-free) in water; it was given in normally increasing amounts $(6 \times 10 \mathrm{ml}$./day of age). The child weighed $3.20 \mathrm{~kg}$ on the


day (analysis B, Table 2). It excreted $40.4 \mathrm{mg}$ amino-acids/100 $\mathrm{mg}$ total nitrogen $\left(\frac{60 \cdot 7}{150 \cdot 2} \times 100\right.$, see analysis $A$, Tables 2,3 and 4$)$. It was therefore a case of pronounced aminoaciduria. It showed no clinical signs of scurvy but the ascorbicacid excretion was particularly low (about $0.5 \mathrm{mg}$. in $24 \mathrm{~h}$ ). It was then given 
'Table 2. Excretion of a-amino-acids and nitrogenous metabolites by a full-term infant 7 days after birth before administration of vitamin $C(A)$ and 5 days later after saturation with $150 \mathrm{mg}$ vitamin $C$ daily $(B)$

\begin{tabular}{|c|c|c|c|c|c|c|}
\hline \multirow[t]{2}{*}{$\begin{array}{l}\text { Amino-acid } \\
\text { or metabolite }\end{array}$} & \multicolumn{2}{|c|}{$\begin{array}{c}\mu \mathrm{mole} / \mathrm{r} 00 \mathrm{mg} \\
\text { total } \mathrm{N}\end{array}$} & \multicolumn{2}{|c|}{$\begin{array}{l}\mathrm{mg} / 100 \mathrm{mg} \\
\text { total } \mathrm{N}\end{array}$} & \multicolumn{2}{|c|}{$\begin{array}{l}\text { Corresponding } \\
\mathrm{N} \text { in } \mathrm{mg} / \mathrm{roo} \mathrm{mg} \\
\text { total } \mathrm{N}\end{array}$} \\
\hline & $A$ & B & A & B & A & B \\
\hline Cysteic acid & $3 \cdot 8$ & $2 \cdot 2$ & 0.57 & 0.33 & 0.53 & 0.03 \\
\hline Taurine & $3 \cdot 3$ & $\mathrm{I} \cdot 4$ & 0.41 & 0.18 & 0.05 & 0.02 \\
\hline Threonine & 36.8 & 16.1 & $4 \cdot 3^{8}$ & $I \cdot 92$ & $0.5 \mathrm{I}$ & 0.22 \\
\hline Serine & $5^{8 \cdot 4}$ & 20.6 & $6 \cdot 13$ & $2 \cdot 16$ & 0.82 & 0.25 \\
\hline Glutamic acid & I I $\cdot 3$ & $3 \cdot 3$ & $x \cdot 66$ & 0.48 & 0.16 & 0.05 \\
\hline Proline & - & $8 \cdot 7$ & - & 1.00 & - & 0.12 \\
\hline Glycine & $228 \cdot 8$ & $49 \cdot 0$ & $17 \cdot 13$ & $3 \cdot 67$ & $3 \cdot 20$ & 0.69 \\
\hline Alanine & $18 \cdot 4$ & $11 \cdot 9$ & $1 \cdot 64$ & I.06 & 0.26 & 0.17 \\
\hline Tyrosine & $I \cdot 9$ & - & 0.35 & - & 0.03 & - \\
\hline Phenylalanine & $I \cdot 9$ & - & 0.32 & - & 0.03 & - \\
\hline Valine & - & 0.5 & - & 0.05 & - & 0.01 \\
\hline Histidine & $25 \cdot 4$ & $11 \cdot 7$ & 3.94 & $I .8 I$ & 1.06 & 0.49 \\
\hline Lysine & $23 \cdot 4$ & $26 \cdot 9$ & 3.84 & $3 \cdot 93$ & 0.74 & 0.75 \\
\hline Tryptophan & - & - & - & - & - & - \\
\hline Urea & - & - & $13^{8 \cdot 12}$ & - & $64 \cdot 65$ & 84.60 \\
\hline Ammonia & $509 \cdot 4$ & $289 \cdot 0$ & 14.92 & $4 \cdot 91$ & $12 \cdot 28$ & 4.05 \\
\hline Creatinine & - & - & $22 \cdot 98$ & - & $8 \cdot 5^{8}$ & 1.04 \\
\hline \multicolumn{7}{|c|}{$\begin{array}{l}\text { Nitrogen re- } \\
\text { covery as per- } \\
\text { centage of total }\end{array}$} \\
\hline
\end{tabular}

Urine vol. $/ 24 \mathrm{~h}$, (A) $83 \mathrm{ml}$. (B) I $82 \mathrm{ml}$. Urea (g/l.), (A) 2.5 (B) 8.71 . Ammonia (g/l.), (A) 0.27 (B) 0.41 . Creatinine (mg/roo ml.) (A) $4 \mathrm{I} .6$ (B) 13.5 . Total $\mathrm{N}$ (mg/100 ml.) (A) I 8 I (B) 480.5 and (mg/24 h) (A) I 50.23 (B) 874.5. Vitamin C (mg/roo ml.) (A) 0.55 (B) 37.5 and (mg/24 h) (A) 0.46 (B) 68.25 .

I $50 \mathrm{mg}$ ascorbic acid daily; it showed evidence of overflow only on the 3 rd day; the child was therefore considered as being possibly in a condition of mild and latent deficiency in vitamin $\mathrm{C}^{*}$.

On the $4^{\text {th }}$ day of vitamin C-enriched diet, a new $24 \mathrm{~h}$ sample of urine was collected (with the use of a micro von Pirket urinal) and analysed (analysis B). The essential features of this test are the following (see Tables 3 and 4):

After vitamin $\mathrm{C}$ treatment:

(I) The urine volume was a little over twice that before treatment; (2) the ascorbic-acid output increased to about 150 times the original level; (3) whereas the overall concentration of nine free amino-acids, plus taurine and cysteic acid was about the same before and after ascorbic-acid administration, the output in

* Ample data for vitamin $\mathrm{C}$ excretion are available for adults. For newborn infants, the information is scanty. We measured therefore ascorbic-acid excretion in eight newly born infants which were all fed since birth on the diet given on page 295, except that in a first series of five of them the diet was reinforced with vitamin $C$. In the first series, the babies excreted $18-4 \mathrm{I} \mathrm{mg}$ ascorbic acid daily whereas in the second series the output was less than $\mathrm{I} \mathrm{mg}$. In these eight instances, the babies were all submitted to a saturation test with a daily load of $100 \mathrm{mg}$ vitamin $\mathrm{C}$ administered by mouth in addition to the vitamin $\mathrm{C}$ supply incorporated in the diet. In the first group, the infants responded immediately by an increased output, whereas in the second group they reached saturation only by about the 3 rd day. 
Table 3. Concentration and output of a-amino-acids and nitrogenous metabolites in the urine of a full-term infant 7 days after birth before administration of vitamin $C(A)$ and 5 days later after saturation with ${ }_{5}{ }^{\circ} \mathrm{mg}$ vitamin $C$ daily $(B)$

\begin{tabular}{|c|c|c|c|c|}
\hline \multirow[b]{2}{*}{$\begin{array}{l}\text { Amino-acid } \\
\text { or metabolite }\end{array}$} & \multicolumn{2}{|c|}{$\begin{array}{l}\text { Concentration } \\
(\mathrm{mg} / \mathrm{r} 00 \mathrm{ml} \text { ) }\end{array}$} & \multicolumn{2}{|c|}{$\begin{array}{c}\text { Output } \\
(\mathrm{mg} / 24 \mathrm{~h})\end{array}$} \\
\hline & A & B & A & B \\
\hline Cysteic acid & $1 \cdot 0$ & $I \cdot 6$ & 0.9 & $2 \cdot 9$ \\
\hline Taurine & 0.8 & 0.9 & 0.6 & $I \cdot 6$ \\
\hline Threonine & $7 \cdot 9$ & $9 \cdot 2$ & 6.6 & $16 \cdot 7$ \\
\hline Serine & $I I \cdot I$ & 10.4 & $9 \cdot 2$ & $18 \cdot 9$ \\
\hline Glutamic acid & $3 \cdot 0$ & $2 \cdot 3$ & $2 \cdot 5$ & $4 \cdot 2$ \\
\hline Proline & - & $4 \cdot 9$ & - & $8 \cdot 9$ \\
\hline Glycine & $3 I \cdot 0$ & $17 \cdot 7$ & $25 \cdot 7$ & $32 \cdot 2$ \\
\hline Alanine & $3 \cdot 0$ & $5 \cdot 1$ & $2 \cdot 5$ & $9 \cdot 3$ \\
\hline Tyrosine & 0.6 & - & 0.5 & - \\
\hline Phenylalanine & 0.6 & - & 0.5 & - \\
\hline Valine & - & 0.3 & - & 0.5 \\
\hline Histidine & $7 \cdot 1$ & $8 \cdot 7$ & $5 \cdot 9$ & 15.8 \\
\hline Lysine & $7 \cdot 0$ & 18.9 & $5 \cdot 8$ & $34 \cdot 4$ \\
\hline Total & $73 \cdot I$ & $80 \cdot 0$ & $60 \cdot 7$ & $145 \cdot 4$ \\
\hline Urea & $250 \cdot 0$ & $871 \cdot 0$ & $207 \cdot 5$ & $1585^{\circ} \circ$ \\
\hline Ammonia & 27.0 & $4 I \cdot 0$ & $22 \cdot 4$ & $74 \cdot 6$ \\
\hline Creatinine & $4 I \cdot 6$ & I 3.5 & $34 \cdot 5$ & $24 \cdot 6$ \\
\hline
\end{tabular}

Table 4. Comparison of composition of $24 h$ specimens of urine of infant described in Tables 2 and 3

\begin{tabular}{|c|c|c|c|}
\hline & A & B & B:A \\
\hline $\begin{array}{l}\text { Volume (ml.) } \\
\text { Density }\end{array}$ & $\begin{array}{c}83 \\
\text { I. o } 84 \\
\text { at } 18^{\circ}\end{array}$ & $\begin{array}{c}\mathrm{I} 82 \\
\mathrm{I} \cdot 0 \mathrm{III} \\
\text { at } 19 \cdot 5^{\circ}\end{array}$ & $\begin{array}{l}2 \cdot 2 \\
-\end{array}$ \\
\hline $\begin{array}{l}\quad \text { Output }(\mathrm{mg} / 24 \mathrm{~h}) \\
\text { Ascorbic acid } \\
\text { Urea } \\
\text { Ammonia } \\
\text { Creatinine }\end{array}$ & $\begin{array}{c}0.46 \\
207 \cdot 5 \\
34 \cdot 5 \\
22 \cdot 4\end{array}$ & $\begin{array}{l}68 \cdot 25 \\
1 \cdot 5^{85} \\
74 \cdot 6 \\
24 \cdot 5\end{array}$ & $\begin{array}{r}149 \cdot 0 \\
7 \cdot 7 \\
2 \cdot 2 \\
1 \cdot 09\end{array}$ \\
\hline Total nitrogen & 150.23 & $874 \cdot 5$ & $5 \cdot 8$ \\
\hline $\begin{array}{l}\text { Urea nitrogen } \\
\text { Ammonia nitrogen } \\
\text { Creatinine nitrogen }\end{array}$ & $\begin{array}{r}96 \cdot 9 \\
28 \cdot 4 \\
8 \cdot 3\end{array}$ & $\begin{array}{l}745 \\
61 \cdot 5 \\
9 \cdot 12\end{array}$ & $\begin{array}{l}7 \cdot 7 \\
2 \cdot 2 \\
I \cdot 09\end{array}$ \\
\hline$\frac{N_{t}-\left(N_{u}+N_{a}+N_{c}\right)}{N_{t}}$ & $\frac{16.61}{150.23}=$ & $\frac{60 \cdot 9}{874.5}=$ & \\
\hline $\begin{array}{l}\mathrm{N}_{\mathrm{t}} \text {, total nitrogen } \\
\mathrm{N}_{\mathrm{a}} \text {, ammonia nitrogen }\end{array}$ & $\mathbf{N}$ & $\begin{array}{l}\text { a nitroge } \\
\text { atinine } n\end{array}$ & \\
\hline
\end{tabular}


$24 \mathrm{~h}$ increased nearly $250 \%$; roughly speaking the output seemed to follow the volume of urine excreted, the concentration being hardly altered. This observation agrees with expectation, as far as free amino-acids are concerned, if the urine excreted were essentially glomerular urine from a kidney with the nephron still incompletely developed, or at least not exerting yet its normal and efficient function of reabsorption; as a matter of fact, we would consider this to be so at birth. It would be interesting to see whether a diuretic effect induced pharmacologically would produce a similar picture.

There are other results, however, that seem to follow dosage with ascorbic acid. The urine volume and the free amino-acid output were both increased two to twoand-a-half times their original value, but the total nitrogen output was nearly six times greater.* Moreover the urea formed in the body and its excretion through the kidney were also considerably increased (to nearly eight times the original level); the ammonia output, however, was only about doubled and the creatinine excretion was hardly altered.

Therefore, when expressed in terms of percentage of the total nitrogen output, the amino-acids excreted in the urine declined after administration of vitamin $\mathrm{C}$, but this apparent decrease was brought about by a much greater production of urea in the body and excretion through the kidney during the same period-notwithstanding an actual increase in the absolute amount of amino-acids passed in the urine in $24 \mathrm{~h}$, which seemed to depend on the increase in volume of urine produced.

When two subjects as different in size as an adult and a newborn infant are compared, it seems necessary to consider the renal secretion of nitrogenous metabolites with reference to the same amount of total nitrogen excreted. But such method may, however, provide insufficient information for adequate comparison between urines passed by the same infant at intervals of a few days.

Fig. I shows the urine chromatograms on the same amount $(2 \mathrm{ml}$.) of urine in two $24 \mathrm{~h}$ specimens obtained from the same infant at 5 days' interval before and after vitamin administration. In each instance, therefore, the curves represent the ninhydrin-positive contents of $2 \mathrm{ml}$. portions of both urines. The ordinate scale in graph $\mathrm{B}$ was expanded $2 \cdot 2$-fold so that the height of each peak would be proportional to the daily output of each constituent. This presentation emphasizes the absolute increase of aminoaciduria in an instance where the proportion of total nitrogen output $/ 24 \mathrm{~h}$ due to amino-acids was reduced.

The peaks of the figure and the corresponding values in Table 3 show that the infant excreted, before receiving vitamin $\mathrm{C}$, nine free a-amino-acids in the following decreasing order of importance, in $\mathrm{mg} / 24 \mathrm{~h}$ : glycine, serine, threonine, histidine and lysine and much smaller amounts of the other amino-acids. After vitamin $\mathrm{C}$ administration, the order was as follows: lysine, glycine, serine, threonine, histidine, alanine, proline and much less of the remaining amino-acids. Proline

\footnotetext{
* The nitrogen intake was about $\mathrm{I} \cdot 45 \mathrm{~g}$ on the 7 th day (analysis $\mathrm{A}$ ) and about $2.50 \mathrm{~g}$ on the 12 th day (analysis B), i.e, about 9.1 and $15.6 \mathrm{~g}$ protein, respectively.
} 



Fig. x. Chromatographic analysis of urine sample of infant described in Table 3. A, 24 h urine specimen before vitamin $\mathrm{C}$ administration (analysis $\mathrm{A}$ ); $\mathrm{B}$, the same after vitamin $\mathrm{C}$ administration (analysis B).

On the left, $100 \mathrm{~cm}$ columns for neutral and diacidic amino-acids. The diagram is cut out between the fractions 300 to 400 , where the chromatogram is empty.

On the right, $15 \mathrm{~cm}$ columns for basic amino-acids and $\mathrm{NH}_{3}$.

The height of the proline peak has been adjusted for its colour factor $(\times 3 \cdot 3)$. The unlabeled peak on the right of histidine, in $B$, is lysine.

and valine were only present after treatment, whereas on the contrary, a trace of tyrosine and phenylalanine disappeared from the urine after treatment.

\section{Conclusion}

The aminoaciduria described in the present paper concerns a 7 -day-old baby born at term. The baby may have been in a condition of a latent vitamin $\mathrm{C}$ deficiency. A considerable modification in its nitrogen metabolism accompanied the administration of vitamin C. A drop in the percentage of total nitrogen excreted in the form of free amino-acids, as well as an abundant output of urea occurred. This effect may be indicative of an improved process of nitrogen metabolism, but at the same time, the absolute amount of amino-acids passed in the urine in $24 \mathrm{~h}$ was actually increased after dosage with vitamin $\mathrm{C}$. This may have been a secondary effect brought about independently of the first one, as the renal function in a newborn child shows a transitory correlation between amino-acid excretion and urine volume. It is conceivable that these distinct effects came into play simultaneously.

So far, this has been our only opportunity to make this complete study of aminoacid excretion in an infant, under the necessary conditions. Similar observations in comparable instances are needed in order to confirm whether vitamin $C$ is actually responsible for the effect described.

\section{REFERENCES}

Crumpler, H. R., Dent, C. E., Harris, H. \& Westall, R. G. (195 I). Nature, Lond., 167, 307. [See also lnt. Congr. clin. Path. I951, London.] 
Dustin, J. P., Moore, S. \& Bigwood, E. J. (1952). Int. Congr. Biochem. II. Paris. Résumés des Communications, p. 354 .

Jonxis, J. H. P. (1951). Voeding, 12, 309.

Jonxis, J. H. P., Smith, P. A. \& Huisman, T. H. J. (1952). Lancet, 263, 1015.

Moore, S. \& Stein, W. H. (1951). F. biol. Chem. 192, 663.

Schram, E., Dustin, J. P., Moore, S. \& Bigwood, E. J. (1953a). Analyt. chim. acta, 9, 149.

Schram, E., Dustin, J. P., Moore, S. \& Bigwood, E. J. (1953b). Analyt. chim. acta, 9, 256.

\title{
Dehydroascorbic Acid in Human Blood Plasma
}

\author{
By C. P. Stewart, D. B. Horn and J. S. Robson, Clinical Laboratory, Royal \\ Infirmary, Edinburgh
}

The existence of dehydroascorbic acid in human plasma

A year ago we (Stewart, Horn \& Robson, 1952, 1953) showed that human blood plasma contains quite considerable amounts of dehydroascorbic acid. Previously it had been generally believed that this substance was not present in blood plasma or was present only in negligibly small concentration. The evidence on which we founded our statement was as follows.

In the first place, a colorimetric method of determining ascorbic acid by its power of reducing indophenol gave results consistently lower than those obtained, in the same plasma, by the method of Roe \& Kuether (1943) which measures dehydroascorbic acid and diketogulonic acid in addition to ascorbic acid. Control experiments with the two methods suggested that the difference was real, and observations on the stability of ascorbic acid in plasma negatived the idea that oxidation of ascorbic acid might be occurring in the plasma (or whole blood) after its withdrawal or during the actual determination with indophenol. Further, treatment of plasma or plasma filtrates with pure hydrogen sulphide produced an increase in the ascorbic acid measured by indophenol exactly equal to the dehydroascorbic acid calculated as being present originally. Not only did these experiments very strongly suggest the presence of dehydroascorbic acid in human plasma - in amounts varying from below 0.1 to $0.36 \mathrm{mg} / 100 \mathrm{ml}$. - but they suggested, equally strongly, the virtual absence of diketogulonic acid, since this substance is not reduced by hydrogen sulphide but reacts with dinitrophenylhydrazine under the conditions used by Roe \& Kuether.

Confirmatory evidence of a similar character was obtained during experiments in which the apparent ratio of ascorbic acid to dehydroascorbic acid was altered, but since our original publication we have sought confirmation by using a different reducing agent in place of the non-specific hydrogen sulphide. Dr Mapson kindly gave us a culture of the Bacterium coli strain which he and Ingram (Mapson \& Ingram, 195I) had shown to be capable of reducing dehydroascorbic acid quantitatively to ascorbic acid. Suspensions of this organism, shown to be fully active by control experiments with aqueous solutions freshly prepared to contain dehydroascorbic acid, were incubated with plasma under the conditions of $\mathrm{pH}$ and anaerobiosis described by Mapson \& Ingram. In each experiment the preformed ascorbic 